\title{
In Memoriam of Professor Roger W.H. Sargent, the Founder of "Process Systems Engineering"
}

\author{
Rafiqul Gani ${ }^{1, *}$ and Ian Cameron ${ }^{2, *}$ \\ 1 PSE for SPEED Company Ltd., Skyttemosen 6, DK-3450 Allerod, Denmark \\ 2 School of Chemical Engineering, Faculty of Engineering, Architecture and Information Technology, \\ The University of Queensland, Brisbane St Lucia 4072, Australia \\ * Correspondence: rgani2018@gmail.com (R.G.); i.cameron@uq.edu.au (I.C.)
}

Received: 20 March 2020; Accepted: 20 March 2020; Published: 30 March 2020

\section{In Memoriam}

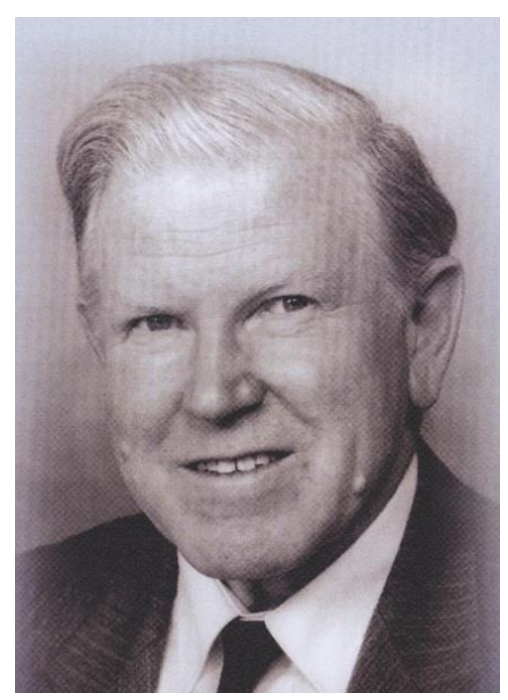

\section{Roger W.H. Sargent}

1926-2018

In September 2018, the global chemical engineering community lost a true pioneer in the field. This Special Issue is in celebration of Roger Sargent's influence, contributions and legacy as the founder of the field of 'Process Systems Engineering' (PSE). His many years, initially at Air Liquide in Paris, and subsequently at Imperial College London laid a foundation that has been built upon by many who did not personally know him, but have benefited through his insights and sustained vision.

Besides his research and industry focus, he was also influential within education and the engineering profession. He held leadership positions such as head of the Department of Chemical Engineering Imperial College, Dean of the City and Guilds College and President of The Institution of Chemical Engineers (UK) and director of the Centre for Process Systems Engineering.

The papers in this issue represent areas that, in many ways, were pioneered by Roger as he and his many students developed new approaches to the integrated design, mathematical modelling and the optimization of complex industrial processes. These developments were facilitated by computer-based tools and a wide range of advanced numerical methods. A number of his direct PhD students and some of their academic descendants are authors of these contributions. 
In remembering his impact, there follows a personal tribute from Arthur Westerberg, one of Roger's PhD students in the early 1960s. Professor Westerberg himself continued ground-breaking contributions in PSE at Carnegie Mellon University (USA).

In the late 1970s, both of us were privileged to complete our PhD degrees under Roger's expert and constructive guidance. We were thankful for his time, patience and encouragement during that period and ongoing friendship.

He will be missed by family, friends and a host of those within his academic family tree. However, he will not be forgotten.

Rafiqul Gani and Ian Cameron.

\section{Tribute to Roger Sargent}

by

\section{Arthur W. Westerberg}

I am going to steal part of the following tribute to Roger Sargent from a message I sent to his son, Philip, just after I learned, sadly, that Roger had passed away.

Many have and will summarize Roger's many contributions to the Process Systems Engineering area. This tribute will be more personal. I was Roger's sixth PhD student, from 1961 to 1964, and, of course, he was a lifelong friend.

Having done a two month summer tour organized for college students in 1959 with Shel Thompson, my roommate at the University of Minnesota, and having Neal Amundson as my undergraduate advisor, who knew just about everyone in academia in the UK, pushed me to apply to go to the UK for my PhD. Negotiations with Kenneth Denbigh, then chairman of the teaching side of the department at Imperial College, garnered me an Assistant Lectureship offer to provide support. After spending a year at Princeton to obtain first an MS degree, I stepped off the ship (on which, incidentally, I met my wife Barbara) knowing no one in London in September of 1961. I remember first visiting the main office of the department at Imperial College and meeting Kenneth Denbigh. After first presenting me his topics, he sent me around to the rest of the department. I entered Roger Sargent's office shortly thereafter, and, of course, Roger had a project for someone who had on his resume experience in using the computer, on projects both at Minnesota and at Princeton. No one in those days would likely have had any computer experience. Furthermore, as we now know, Roger was into computers and their use in process design and control, with his several years at Air Liquide in Paris in the 1950s. Mind you the computers anyone would have had then were toys by today's standards, but he could see the potential and wanted to be in the business of developing that area as a research area. As I came with an Assistant Lectureship, an entry level faculty position, he insisted I join the faculty for morning coffee, lunch and coffee, and afternoon tea. Thus I saw him at least three times almost every day and had lots of time to interact with him on my project. Our paper from that work was really two parts: a core dump of his ideas on how computers would contribute to design and control in our field and a presentation of the ideas in my work on how to shoehorn a flowsheeting calculation onto a vastly undersized computer. Many people in industry told me they were in the modeling departments of their companies because they mentioned they had read that paper in their interviews.

I worked for two years with Control Data in San Diego before joining the Chemical Engineering Faculty at the University of Florida in 1967. By then Roger had given a well appreciated talk at the invitation of the AIChE and then published as a paper in CEP. This talk and the resulting paper again presented his views on PSE. If memory serves, it had about 50 references to relevant papers from many different fields. I remember going on a hunt to collect and review all those papers. It got me off to a running start on my career when I joined the faculty in Florida.

A bit of humor: In 1990 Roger received the CAST Division Computing in Chemical Engineering Award and gave his acceptance speech at the November AIChE meeting. As all know who have 
heard Roger give a presentation, his talks were seldom if ever done within the prescribed time limit. We were all sitting at the tables listening and, by this time, consuming our desserts and drinking coffee. I remember clearly lifting my coffee cup for a sip. When I looked down, the wait staff has taken away the saucer. Our table lit up with laughter. The wait staff were ready to go home.

Over the years I had many occasions to interact with Roger. We were at many meetings together. I visited Imperial College to give the annual Sargent lecture, Roger came to Carnegie Mellon University to give a departmental seminar (we have three former and current faculty members who are his students: the oldest: me, Ignacio Grossmann and Erik Ydstie). In the late 1980s, as we were just starting our Engineering Design Research Center at CMU, Roger led a group at Imperial College to create a related organization aimed at process systems engineering. As director of our center, I reviewed his proposal and others, and clearly this was the project to fund among those I saw. After, I had many occasions to visit his centre. I have to admit, he seemed to tolerate administration (certainly much more eagerly that I did) and held many significant such positions at Imperial College and in the Institute of Chemical Engineers, as well as running this centre. So his legacy is much more than his research.

Finally, he is the top node of a huge academic family tree (http://titan.engr.tamu.edu/Sargent_tree/ index.php), that is "the tree" for all of us lucky enough to have been on his.

We will all miss him.

Author Contributions: R.G. and I.C. wrote the In Memoriam preface. A.W. wrote the personal tribute to Professor Roger Sargent. All authors have read and agreed to the published version of the manuscript.

Conflicts of Interest: The authors declare no conflict of interest.

(C) 2020 by the authors. Licensee MDPI, Basel, Switzerland. This article is an open access article distributed under the terms and conditions of the Creative Commons Attribution (CC BY) license (http://creativecommons.org/licenses/by/4.0/). 